\title{
Architect's Role in the Period of Digitalisation of the Construction Industry
}

\author{
Ing. Aleš MAREK
}

Tutor: prof. Ing. Miloslav Pavlík, CSc.; Ústav stavitelství I, Fakulta architektury, České vysoké učení technické v Praze, Česká republika

E-mail address: ales.marek@fa.cvut.cz

\begin{abstract}
This paper deals with the changing role of chartered architects in the era of digitalization in the construction industry and the resulting new demands on their key activities during the design process.
\end{abstract}

KEYWORDS: BIM; CDE; EIR; BIM protocol; BEP

\section{The goal}

This paper aims to solve the current situation of the digitalization of the construction industry, including BIM $^{1}$ method, and its effects on architects' key activities in the area of building design.

\section{Research questions}

I have decided to narrow the wide area of digitalization into selected areas for work focus:

a) Architectural educational activities at the FA CVUT'2 are: Master study program, Ph.D. study program, including research and innovations and $\mathrm{CZV}^{3}$;

b) Key activities of authorized persons - chartered architects in the field of building design according to the SASS ${ }^{4}$;

c) The state of legislation and its expected future development; 
d) Experiences in BIM design in an architectural/engineering studio.

Based on the above-mentioned division of objectives, I asked myself the following research questions:

Re. a) How does the process of education respond to current requirements; how should the present university education be modified, and how should the CZV for practising architects be prepared?

Re. b) What are architects' key activities affected by the digitalization and BIM and how does SASS have to be modified or extended?

Re. c) In which documents are architects' key activities specified and how do these documents have to be modified or extended?

Re. d) How could experiences in private studios be implemented in the education process?

\section{Digitalization in the Czech Republic}

The professional environment in the $\mathrm{CR}^{5}$ is changing due to Digital Czechia ${ }^{6}$ and Construction Industry $4.0^{7}$.

\section{Defining the area of architects' crucial activities}

I selected the following areas for analysis to answer the research questions:

a) The architect's activity area:

I selected the segment comprising the construction building;

b) Chartered architects' key activities:

Covers the following documents:

1. Principles of providing a licence for the individual performance of architectural practice;

2. Act No. 360/1992 Coll., (Authorization law)

3. Standard of architects' services and their documents for architectural design ${ }^{10}$;

and I specified, concerning the above-mentioned areas, architects' general activities:

1. General job management including administrative and technical steering of design works;

2. Performance of the position of an architect-in-charge, including elaboration of the complete architectural design for the whole project;

3. Management and coordination of a design team;

4. Performance of an architect's supervision.

I divided chartered architects' activities, based on Service Phases ${ }^{11}$ (SP), into three stages: 
1. Pre-project preliminaries:
1. SP 1
Project Initiation;
2. SP 2
Preliminary - Concept Design;

2. Project Design:
1. SP 3
Land Zone Permit Design;
2. $\mathrm{SP} 4$
Building Permit Developed Design;
3. SP 5
Detailed Design;
4. SP 6
List of Works and Deliverables ;

3. Execution phase:
1. SP 7
Architect's Supervision.

Each SP includes standard services (SS) and non-standard (NSS) services related to BIM that I consider as NSS:

1. SP 1: preparation of contract annexes, i.e. $\mathrm{EIR}^{12}$, $\mathrm{BIM}_{\text {protocol }}{ }^{13}$ and $\mathrm{BEP}^{14}$ template;

2. SP 2 to SP 7: BEP elaboration for each SP, BIM model development, installation and operation of $\mathrm{CDE}^{15}$;

3. SP 3 and SP 4: electronic submission of the proposal to permit the project.

All NSS' have effects on all major parts of the architect's work contract, i.e. the subject matter of the performance, the fee and the time plan.

\section{State of legislation and documents regarding BIM}

1. Current laws and implementing decrees:
a. The novelty of the Building Code, 3. 12. 2017;
b. The novelty of Regulation No. 499/2006 Coll., 7. 12. 2017;
c. CSN ISO 19650-1, CSN ISO 19650-2;
d. Act No. 47/2020 Coll., 26. 2. 2020, will come into legal effect on 1. 7. 2023;

2. Current laws and documents concerning public commissions:
a. Regulation No. 169/2016 Coll., 7. 12. 2017;
b. The Concept of introducing the BIM method in the Czech Republic ;
c. The imposing of a duty to use BIM for above-limit commissions for construc- tion work from Jan 2022; Government Decree, 25. 9. 2017, the legal effective- ness thereof will be changed to July 1, 2023.

The new Building Code is currently being prepared for submission to the Parliament of the CR. 
3. Legislation under preparation:

a. The New Building Code will become legally valid during the spring of 2021 and will be effective from July 1, 2023;

b. Regulation No. 499/2006 Coll. must be modified according to the analysis of Regulation No. 268/2009 Coll. and must be legally effective from July 1, 2023;

c. The Act on building information modelling and digital modelling of the built environment, ver. July 29, 2020, assumed resolution of the Parliament, 2021.

All current and prepared laws must be coordinated in terms of materiality and time.

\section{A sequence of activities of architects using the BIM method}

Using BIM has special consequences in all SPs:

a) The architect will use digital project source documents;

b) The BIM model allows for the use of another software for expert models and resolution of clashes cooperate and share sub-models with other process participants;

c) The architect will apply electronically for building permit(s).

All of the above-mentioned purposes require the conversion of the BIM model to a machine readable IFC standard.

\section{The research and data processing method}

I analysed and assessed the intersection of architects' activities areas with reference to BIM.

I collected the data and assessed the knowledge according to my experience from working in the following fields:

a) Design practice in AED project, a.s.:

a. Thirty-two years of experience in using CAD software and ten years of using BIM;

b. The project assessment of The Headquarters of the CSOB - SHQ, awarded Building of the Year 2019, regarding BIM design where all SPs were carried out using BIM;

b) Lecturing at the FA CVUT:

a. I established a new subject, $\mathrm{DC}^{18}{ }^{18}$, focusing on BIM;

b. I established a platform to develop baccalaureate projects using BIM;

c. I founded a program of $\mathrm{CZV}$; 
c) I am active in the work groups Digitalization and Standards and Fees of the $\mathrm{CKA}^{19}$;

d) I work on committees at $\mathrm{MPO}^{20}, \mathrm{MMR}^{21}$, ČKAIT ${ }^{22}$ dealing with BIM.

\section{Results of my work and recommendations for further practice}

My recommendations for the future according to the following areas:

a) Architectural design practice:

i) To define new positions (BIM manager, BIM coordinator, BIM modelmaker) and determine their workload and responsibilities;

ii) The assessment of the project The Headquarters of the CSOB - SHQ;

b) Legislation:

i) Changes must be made in current legislation, mainly in the following areas: The BIM model must be defined as the one and only binding source of information, requirements for the $\mathrm{CDE}$ must be set up and the $\mathrm{DDS}^{23}$ must be specified in its graphic and non-graphic form for each PS stage;

ii) Legislation must be coordinated according to time schedules, including a transition period;

c) CKA:

i) Intense cooperation with MMR, MPO and $\mathrm{CAS}^{24}$;

ii) The modification of SASS;

iii) The time allowance change in the Calculator for buildings ${ }^{25}$;

iv) Education of architects based on the best practice;

d) Lecturing at the FA CVUT in Prague:

i) To define requirements on the extending of architects' qualification;

ii) To implement experiences from the pilot year of DC1 and the Baccalaureate project;

iii) The knowledge from the tuition has to be implemented into CZV;

iv) To define software literacy regarding the ability to elaborate the BIM model.

\section{Work context}

This work was developed within the context of the current situation in the CR and coordination with EU legislation. 


\section{Notes}

1. Building Information Modeling and Management

2. Faculty of Architecture CVUT in Prague

3. Lifelong Education

4. Standards of Architects'Scope of Services, Czech Chamber of Architects, April 2018

5. Czech Republic

6. Digital Czechia v. 2.0, The Road to the Digital Economy, MPO, March 12, 2020

7. 7th meeting of the Government Council for Construction of the Czech Republic, October 18, 2017

8. Czech Chamber of Architects, April 10, 2014

9. Last change pursuant to Act No. 459/2016 Coll., effective from January 1, 2017

10. Czech Chamber of Architects, April, 2018

11. According to Standards of Architects'Scope of Services, Czech Chamber of Architects, April 2018

12. Employer's Information Requirements

13. Czech Agency for Standardization, October 12, 2018

14. BIM Execution Plan

15. Common Data Environment

16. Ministry of Industry and Trade, September, 2017

17. Czechoslovak Commercial Bank

18. Design Computing 1

19. Czech Chamber of Architects

20. Ministry of Industry and Trade

21. Ministry of Regional Development

22. Czech Chamber of Authorised Engineers and Technicians in Construction

23. Building Data Standard

24. Czech Standardization Agency

25. https://www.cka.cz/cs/pro-architekty/kalkulacky/pozemni-a-krajinarske-stavby 